\title{
PERCEIVED INTERACTIONAL JUSTICE OF SERVICE RECOVERY AND POST- RECOVERY SATISFACTION: A STUDY OF DOMESTIC AIRLINE CUSTOMERS IN SOUTH WEST NIGERIA
}

\author{
Ogunode Philips Olatunde and Prof. (Ven.) A. D. Nkamnebe \\ Department of Marketing, Nnamdi Azikiwe University, Awka, Anambra State, Nigeria \\ Correspondence E-mail: philips29g@yahoo.com
}

Cite this article:

Ogunode P.O., Nkamnebe A.D. (2021), Perceived Interactional Justice of Service Recovery and Post-recovery Satisfaction: A Study of Domestic Airline Customers in South West Nigeria. British Journal of Management and Marketing Studies 4(3), 51-61. DOI: 10.52589/BJMMS9QQ31IOX.

\section{Manuscript History}

Received: 5 July 2021

Accepted: 25 July 2021

Published: 30 July 2021

Copyright $\odot 2020$ The Author(s). This is an Open Access article distributed under the terms of Creative Commons AttributionNonCommercial-NoDerivatives 4.0 International (CC BY-NC-ND 4.0 ), which permits anyone to share, use, reproduce and redistribute in any medium, provided the original author and source are credited.
ABSTRACT: This study examined perceived interactional justice of service recovery and post-recovery satisfaction: a study of domestic airline customers in south west Nigeria. This study adopted the perceived justice theory to service recovery with the three dimensions of justice underpinning the study's conceptual framework/research model. Quantitative research design was employed. The unit of analysis comprised of domestic airline customers in south west geopolitical zone of Nigeria. Quota and purposive sampling were the sampling techniques and a sample of 1,998 respondents was statistically drawn using Cochran. Questionnaire was the research instrument; exploratory factor analysis through principal component extraction method was used to statistically measure construct validity while Cronbach Alpha was used to establish the reliability of the instrument. Hypothesized relationships in the path diagram resulting from the research model were tested using Partial Least Square Structural Equation Modeling (PLSSEM) with the aid of $I B M^{\circledR} S P S S^{\circledR} A M O S^{T M} 25$. The finding of this study showed that interactional justice had significant and positive influence on post-recovery satisfaction. It was recommended that airline companies operating in the study area should focus more attention to interactional justice by ensuring prompt response, politeness, listening to customer's complaints individually, and makes good efforts to tackle the complaints in a satisfactory manner.

KEYWORDS: Perceived justice, Interactional Justice, Service Recovery, Post-Recovery Satisfaction. 


\section{INTRODUCTION}

Globally, the airline industry is reputable for its contribution to the growth and development of many nations. The developments of a vital sector such as this will speed up economic growth and generate some economic benefits. According to Chidi and Izuwah (2019), about 254,500 Nigerians and non-indigenes have been gainfully engaged by the Nigeria airline industry and contribute US\$940 million (\#184.7 billion) to national GDP. This is an indication that the sector is germane when it comes to revenue generation through personal income and business taxes. The airline industry plays a vital role in the area of work and leisure to tourists all over the world. The sector also helps promoting and improving the living standard of people within and across nations. This makes the airline industry so crucial to any economy that is willing to develop, pave way for globalization, facilitates trade and tourism development (Ladele, 2012).

According to Ladele (2012), as nations develop, the needs for air transportation also increase due to the growth in the citizens' disposable income. This shows that there is great potential for growth in the industry if properly managed.

More so, Stephens (2009) established that the Nigerian airline industry will continue to grow at an average rate of $15 \%$ domestic traffic so that by 2019 it would have risen to $12,461,043$ million passengers. With this growing rate, the airline industry should not be handled with levity and should be a major of the nation.

However, Amba and Danladi (2013) have highlighted some problems which are common to the airline industry which often hinder smooth service delivery. He listed them to include high cost of operation and maintenance, inadequate funding, lack of transparency, poor managerial skills, lateness in responding to emergency occasioned by sudden air mishap and poor service delivery caused by both mechanical and human errors.

Owing to the numerous gains that accrued to developing nation such as Nigeria from this sector, the industry is best appreciated if effort is geared toward improving the service it provides to its ever-discerning customers in order to minimize any form of service failure that may negatively impact on the growth of the sector.

For effective competition among service firms and specifically in the airline industry in particular, provision and delivery of high-quality service is not negotiable and should be handled with all the seriousness it demands (Zeithaml, Berry and Parasuraman, 1993). Due to the complex nature of the airline industry, there is need for synergy among the airport, airline companies and employees to be able provide quality services that can meet passengers' expectation.

According to Chang, Chen and Chang (2008), airline companies are confronted with both internal and external disruptions that could trigger service failures. The manner in which service firms respond to a service failure (service recovery) has the the potential of placing an airline at advantage. The way an organisation respond to a service failure could either restore customer satisfaction, increase loyalty, or trigger negative emotion which drive the client to a competitor. 
According to Sparks and McColl-Kennedy (2001), service recovery is capable of restoring a dissatisfied customer and makes them develop positive attitude toward the offers of the organization. Also, studies such as McDougall and Levesque (1999) clearly stated that effective service recovery strategies such as assistance plus compensation had great impact on post recovery satisfaction. In another study by Yaya, Marimon and Casadesus (2013), it was discovered that service recovery had a significant effect on customer satisfaction, perceived value and post recovery intention. This view was supported by Mostafa, Lages and Saaksjarvi (2014). All aforementioned findings support that effective service recovery strategies have enormous potential of returning an unhappy, disgruntled and dissatisfied customer back to an organisation as a happy customer. Hence the need for service recovery in the airline industry is inevitable.

\section{Statement of Problem}

The widespread customer dissatisfaction and rising magnitude of unresolved complaints occasioned by airline service failure in the Nigeria airline industry is the first thing that triggered this study. As reported by Phillips Consulting (2015), the growth in the Nigeria airline industry has resulted in influx of passengers for both local and international destinations exceeding 15 million in 2014. The growth in the sector has continued to mount pressure on airport managers, airline companies, employees and airport facilities. Beside rivalry among airlines, there are problems of satisfying the changing needs of customers. Many airport facilities are not enough, while many airline passengers complain about flight cancellations, missing luggage, poor ticket services, check in rejection, inefficient staff and other related problems which have combined to inhibit efficient service delivery and customer satisfaction in the airline industry.

Furtherance to this, the majority of studies on service recovery to recent times have largely focused attention either on the financial sector, online retailers or restaurant service. On financial sector by Michel, (2001), Chebat and Slusarczyk (2005); studies on online retailers include: Lee and Park (2010), Wang and Mattila (2011); on restaurant service include studies by Mattila (1999), Mattila and Patterson (2004). Thus, the research on perceived justice of service recovery among airline customers has been inadequate and relatively not much has been done to unravel the perceived justice of service recovery on post recovery satisfaction among airline customers in South West Nigeria.

Also, different studies on service recovery strategies have been carried out from different perspectives (Carew, 2010; Park, 2004 and Lowenstein, 1995) and each proffering different strategies that could influence customers' satisfaction (Ahmad, Ghazali and Othman, 2013; Akbar and Alaudeen, 2012; and Zemke \& Bell, 1990). Service recovery strategies ranging from apology (Zemke and Bell, 1990), problem solving (Battaglia, Borchardt, Afonso and Pereira, 2012), open explanation (Conlon and Murray, 1996; Boshoff, 1999), compensation (Boshoff, 1999), follow up (Ennew and Schoefer, 2003), and the findings show varied results; thus, causing and informing different growth policy implications. As noted by Tabassum and Rahman (2012), service recovery strategies may differ as a result of differences in culture, climate, social-economic status, e.t.c. Due to differences in the findings of researchers; it is not yet clear which service recovery strategies influence post recovery satisfaction among inbound airline customers in South-Western Nigeria. 
It is against this background that this study specifically examines the influence of perceived interactional justice of service recovery on post recovery satisfaction. It also investigates the comparative influence of demographics on perceived interactional justice of service recovery and post recovery satisfaction.

\section{REVIEW OF RELATED LITERATURE}

\section{Service Recovery}

According to Gronroos (1988), service recovery is the steps taken by a service provider to tackle complaints by customers concerning service failure. Gronroos' definition was reiterated by Zeithaml, Bitner and Gremler (2009) and Buttle (2009) who see service recovery as the efforts put in place to respond proactively to incidence of service failure. Piyali (2011) view service recovery as the strategies of ensuring that the right things are done right after experiencing something abnormal in service delivery. The trio of Miller, Craighead and Karlvan (2000) in lending their contributions refers to service recovery as the actions deliberately designed by service organisations to tackle problems, change negative attitudes of aggrieved customers and retain them.

The various perspectives of various scholars as cited above bother on organisations' reactions to cases of service failures. It is clear from the definitions above that service recovery involves steps put in place by firms to solve problems after service has been provided (Zeithamal et al 2009; and Buttle 2009) and from unhappy clients who may lodge his/her complaint after encountering unpleasant services (Gronroos, 2008; Johnston and Michel, 2008; Miller, Craighead and Karwan, 2000 and Hart, Heskett and Sasser, 1990). From the cited definitions, it is clear that cases of service failure are unavoidable and that organisations must put measures in place to tackle complaints as they occur so as to ensure service recovery management. Also, it shows that service recovery efforts should be established by companies after the incidence of service failure. It is vivid from these enormous definitions that frantic step is required to take sufficient effort to proffer solutions to varieties of problems facing organisations after service failure. These pools of definitions indicate that service recovery should be seen as been a reactive effort which is only introduced when failures surfaces. The definitions should have also viewed service recovery as a pro-active effort where deliberate actions are taken to prevent failure from occurring or will be tackled at the emerging stage (Skinner et al 2008; and Meuter and Michel, 2008) instead of exhibiting care free attitude which may be too costly for the organization in its effort to recover aggrieved customers. Adding to the diverse definitions of service recovery, Miller et al (2000) see it as situations even where if no complaint is lodged. This strategy is used by most sensitive organisations that have zero tolerance service failures as they try to unearth failure cases ever before it gets to the notice of customers.

Sequel to the arrays of definitions from different school of thoughts, this study has adopted the definition of service recovery by Zeithaml et al (2009). To this end, the adopted definition of service recovery for this study is "the measures put in place by firms to disallow and react quickly to service failure". 


\section{Interactional Justice}

Interactional justice has to do with the conduct exhibit by the help of the organisation while treating the client during the assistance recuperation measure (Tax and Brown, 1998). Blodgett et al. (1997) referred to certain researchers and expressed that interactional justice implies the specialist co-op's mentality (regarding, graciousness, awareness, or impoliteness) while collaborating with the clients during the critical thinking measure. As indicated by Blodgett et al. (1997), five components of interactional justice can be distinguished. They include: control measure, choice control, availability, course of events/speed, and adaptability; while a couple of instances of interactional justice are honesty, definite clarification, disposition, accommodation, affectability, interest, lowliness, compassion and affirmation, transparency, and consideration.

Buttressing further, Blodgett et al. (1997) showed the significance of interactional justice in the investigation of service disappointment and recovery.

In their exact exploration, Tax, Brown, and Chandrashekaran (1998) attested that interactional justice is a solid indicator of client trust and fulfillment. Also, an overview by Namkung and Jang (2009) on cafés in the United States uncovered that interactional justice can improve client maintenance and increment in the degree of consumer loyalty. Collie, Sparks and Bradley (2000) presented a comparable reason in their exploration on the hospitality business that the degree of fulfillment is dictated by apparent interactional justice

As noted earlier, a number of perceived justices of service recovery studies have empirically proven that perceived justice of service recovery will enhance customer satisfaction. For instance, studies by McCollough, Berry and Yadav (2000) have empirically shown that distributive justice and interactional justice are strong indicators for post-recovery satisfaction. Spark and McColl-Kennedy (2001) established the correlation between perceived justice (distributive, procedural, and interactional) and customer satisfaction in the hospitality sector. Similar opinion was shared by Holbrook Jr. and Kulik (2001); their studies showed that justice is essential in knowing a consumer's response in a service setting. It is therefore well established in extant service recovery literature that perceived justice of service recovery is a key factor and predictor for post recovery satisfaction. Thus, we hypothesize as follows:

$\mathrm{H}_{1}$ : Perceived interactional justice of service recovery will positively influence post recovery satisfaction.

\section{Theoretical Perspective}

This study is anchored on justice theory because of it adequacy in measuring perceived justice of service recovery. The theory is on the three components of justice which are: distributional justice, procedural justice, and interactional justice (Blodgett et al., 1993; Clemmer and Schneider, 1996; Smith et al., 1999; Tax et al., 1998). More so, the theory was considered appropriate because majority of the studies on service recovery have often found justice very suitable (Solomon, 2004; Schiffman and Kanuk, 2007; Rio-Lanza et al., 2008). More importantly, this theory aligns significantly with the present study due to it perspective and it reflection of perceived justice of service recovery. 


\section{MATERIALS AND METHODS}

This current study was conducted using the survey method. A significant sensible number of service recovery contemplates that have utilized study technique includes Ellywati and Purwanto (2012), Nikbin et al. (2010), Nek Kamal (2009), (Nikbin et al., 2010), Cho (2013), Mansori, Tyng, and Ismail (2014), Kim, Kim, and Kim (2009), and; Chang and Chang (2010). This research was executed in the South West geopolitical zone of Nigeria. Specifically, the study areas include Lagos, Oyo and Ondo states. These three states were used because they are the three (3) states within the south west with functional airports. The aggregate of individual person or object for investigation, or the totality of the units of analysis is called the study population (Okeke, et al,. 2012). The population of this research comprised of domestic airline customers in South-West geo-political zone of Nigeria. Hence, focus was on the three airports in the zone (that is, Murtala Mohammed International airport, Ikeja, Lagos state; Akure airport, Ondo state and Ibadan airport, Oyo state). Thus, the population of study is unknown since we cannot ascertain the number of domestic airline customers who have experienced service failure with exactitude through a secondary source. This study employed both quota and purposive sampling techniques. Quota sampling was to ensure that respondents from the various demographic attributes partake in the sample. Quota sampling aims at ensuring that the selection of potential respondents is based on some prespecified quotas for either demographic characteristics or certain behaviours through disproportionately (Okeke and Eze, 2012).

The number of airline customers in the south west geopolitical zone who have encountered service failure is unknown. Due to this, Cochran's formular for calculating sample from unknown population was used following the yardsticks (Tull and Hawkins, 1993): allowable error margin $\left(\mathrm{e}^{2}\right)$, level of confidence to be obtained $\left(\mathrm{z}^{2}\right)$ and an estimated variance for the population $\left(\underline{\alpha}^{2}\right)$. Therefore, the formula used in determining the sample size was:

$$
\mathrm{n}=\frac{\mathrm{z}^{2} \alpha^{2}}{\mathrm{e}^{2}}
$$

As indicated by Field (2009), the coefficient Z., for a 95\% degree of certainty is 1.96 and as per Tull and Hawkins (1993), the change $\alpha^{2}$ for a 5 point Likert scale, is 1.3. A five point interval Likert scales was utilized to quantify the perceived justice of service recovery and post recovery satisfaction.Therefore, the sample size for this research is statistically calculated as follows:

$$
\mathrm{n}=\frac{1.96^{2} 1.3}{0.05^{2}}=1,998
$$


A sample size of 1,998 airline customers was purposively selected from the three locations in this order: Murtala Mohammed International airport, Ikeja (1,400); Akure airport (249) and Ibadan airport (349). The instrument used for collecting primary data is the questionnaire. Moody (2012) sees questionnaire as a document that contain series of questions or statements that are meant to elicit responses from the selected respondents.

Exploratory Factor Analysis (EFA) through principal component extraction method was used to statistically measure construct validity of the instrument. The factor loading of the items were used to ascertain the Average Variance Extracted (AVE). The KMO and the Barlett test were utilized to decide the adequacy of the sample size. As indicated by Kaiser (1974), if the result of the Kaiser-Meyer-Olkin (KMO) is greater than 0.5, this implies that the question really measured the variables of the study. Additionally, Cronbach's Alpha method of reliability was used to establish the reliability of the instrument. The researcher administered the instrument on 50 respondents who were not part of the target sample. The scores obtained 'were subjected to statistical analysis using Cronbach's Alpha statistics at 0.05 level of significance. Reliability coefficients of 0.672 and 0.957 were obtained on "perceived distributive justice and post recovery satisfaction "subscales respectively while the overall reliability coefficient was 0.957 .

Partial Least Square Structural Equation Modeling (PLS-SEM) with the aid of Smart PLS software was used to test and confirm interrelationship among the variables posited by the conceptual framework and to ensure goodness of fit to the conceptual model.

\section{RESULTS}

Research Hypothesis: Perceived interactional justice of service recovery will positively influence post recovery satisfaction.

Figure 1 displays the path diagram and standardized estimates of the influence perceived interactional justice on post recovery satisfaction. Gender, age, income and travel frequency were specified as control variables. 


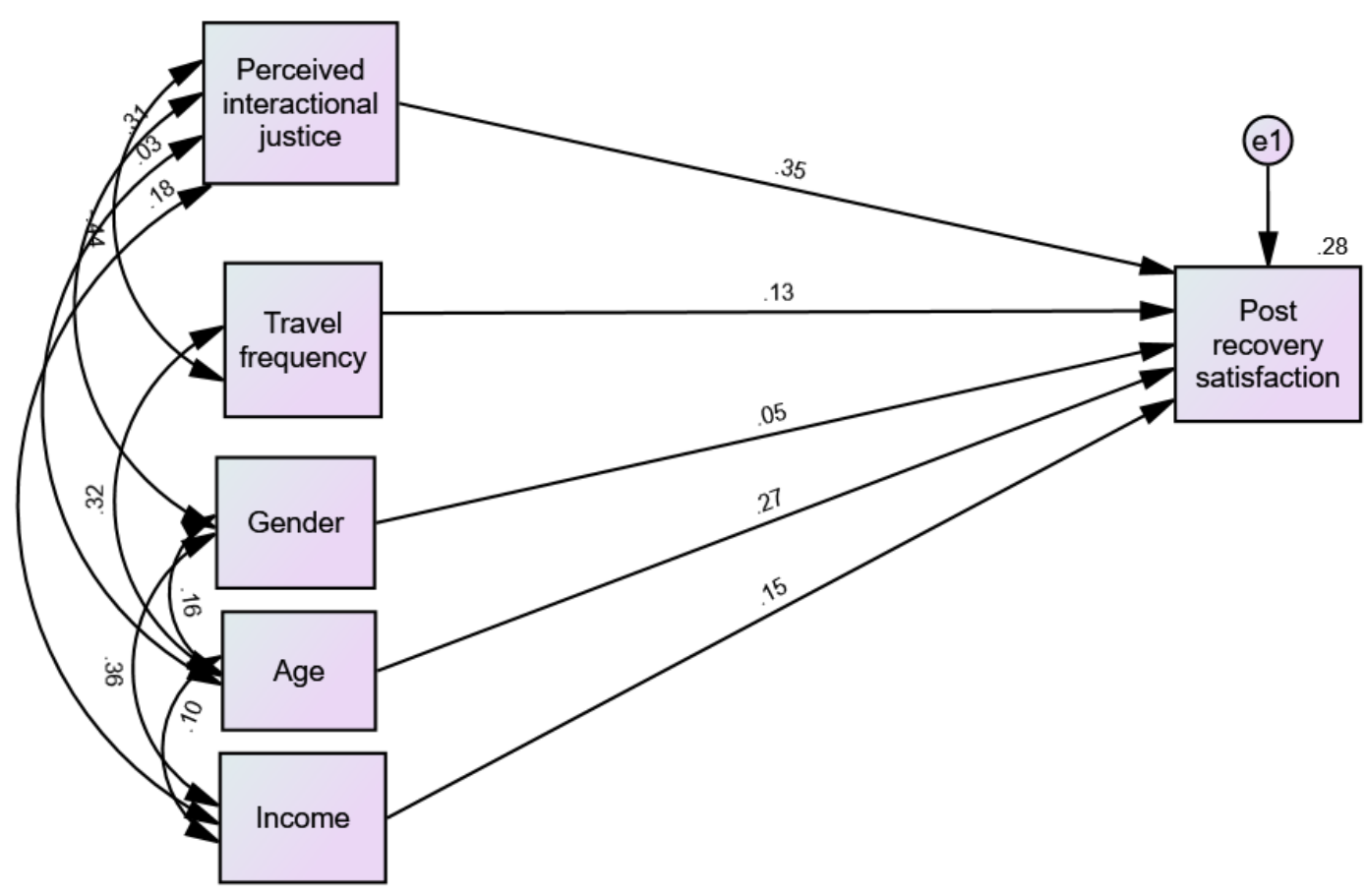

Figure 1: Direct influence of perceived interactional justice on post-recovery satisfaction controlling for socio-demographic variables

Table 1 shows the results of path analyses with p-values. The model fit was very good, $\chi^{2}(2)$ $=8.27, \mathrm{p}=.02 ; \mathrm{CFI}=.99 ; \mathrm{RMSEA}=.04[90 \% \mathrm{CI}=(.02, .07)], \mathrm{SRMR}=.02$. Results show that perceived interactional justice was significant on post-recovery satisfaction $(\beta=.35, p<$ .001). Specifically, an increase in perceived interactional justice predicted an increase in postrecovery satisfaction. The control variables, gender $(\beta=.05, p=.02)$, age $(\beta=.27, p<.001)$, income $(\beta=.15, p=.009)$ and travel frequency $(\beta=.13, p<.001)$ were significant on postrecovery satisfaction. Specifically, being a female, older, having a higher income and higher travel frequency were associated with post-recovery satisfaction. The model explained 28\% variance in post-recovery satisfaction.

Table 1: Direct influence of perceived interactional justice

\begin{tabular}{lllrrr}
\hline & & Estimate S.E. & C.R. P-value \\
\hline Post-recovery satisfaction $<---$ & Interactional justice & .29 & .02 & 15.38 & $<.001$ \\
Post-recovery satisfaction $<---$ & Gender & .60 & .26 & $2.31<.001$ \\
Post-recovery satisfaction $<---$ & Age & 3.51 & .27 & 13.11 & $<.001$ \\
Post-recovery satisfaction $<---$ & Income & 2.25 & .30 & 7.43 & $<.001$ \\
Post-recovery satisfaction $<---$ & Travel frequency & .86 & .16 & $5.53<.001$ \\
\hline
\end{tabular}




\section{DISCUSSION}

The research question sought to empirically examine the effect of perceived interactional justice of service recovery on post recovery satisfaction among domestic airline customers in the study areas. Structural Equation Modeling was used to test the hypothesis. Results show that perceived interactional justice was significant on post-recovery satisfaction $(\beta=.35, p<$ $.001)$. Specifically, an increase in perceived interactional justice predicted an increase in postrecovery satisfaction. The control variables, gender $(\beta=.05, p=.02)$, age $(\beta=.27, p<.001)$, income $(\beta=.15, p=.009)$ and travel frequency $(\beta=.13, p<.001)$ were significant on postrecovery satisfaction.

This finding is strongly supported by a number of previous quantitative studies. The finding by Hocut and Stone (1998) showed that giving employees' self-sufficiency to deal with a service recovery circumstance would altogether reduce rate of service and improve customer satisfaction. In like manner, the outcome of this study also corroborated the multiple assertion of (Blodgett et al., 1993; McColl-Kennedy and Sparks, 2003). According to their independent studies, it was found that interactional justice which could be displayed in the form of regret, versus expression of remorse from the service firms, politeness and sympathy all have the potential of returning a disgruntled customer back to a state of satisfaction.

\section{CONCLUSIONS}

This study investigated the influence of perceived interactional justice of service recovery on posts recovery satisfaction, a study of airline customers in the south west geopolitical zone of Nigeria. After a comprehensive relevant analysis, the model fit was very good, $\chi^{2}$ $(2)=8.27, \mathrm{p}=.02 ; \mathrm{CFI}=.99 ; \mathrm{RMSEA}=.04[90 \% \mathrm{CI}=(.02, .07)], \mathrm{SRMR}=.02$. Results show that perceived interactional justice was significant on post-recovery satisfaction $(\beta=$ $.35, p<.001)$. The finding shows that perceived interactional justice has positive and significant influence on post recovery satisfaction in the study area and is therefore a good predictor of post recovery satisfaction in south west Nigeria. Notwithstanding, interactional justice has the least influence on post recovery satisfaction. The implication of this finding is that employees in the airline industry should learn to relate well with their clients and issues that bother on interactional justice should be given further attention in the airline industry.

\section{RECOMMENDATIONS}

Airline companies operating in the study area should focus more attention to interactional justice by ensuring prompt response, politeness, listening to customer's complaints individually, and make good efforts to tackle the complaints in a satisfactory manner. Mechanism could be in place to identify and nip service failure in the bud before it gets to the knowledge of customers. This will boost customers' trust and re-purchase intention. 


\section{REFERENCES}

Akbar, Y. A. A., and Alaudeen, M. S. S. (2012). Determinant of factors that influence consumer in choosing normal full-service restaurant : case in seri Iskandar, Perak, Malasia. South East Asian Journal of Contemporary Business, Economics and Law. 1, 137-145.

Battaglia, D., Borchardt, M., Afonso Sellitto, M., and Medeiros Pereira, G. (2012). Service recovery: a method for assessing performance, Business Process Management Journal, 18(6), 949-963. http://dx.doi.org/10.1108/14637151211283366

Boshoff, C. (1999). RECOVSAT: An instrument to measure satisfaction with transactionspecific service recovery. Journal of Service Research , 1 (3), 236-249

Chang, H., Chien-Ming, T., and Lu-Chun, L. (2008). The influence of service recovery on perceived justice under different involvement level: an evidence of retail industry, Contemporary Management Research. 4(1) 57-82.

Choi, B. and La, S. (2013). The impact of corporate social responsibility (csr) and customer trust on the restoration of loyalty after service failure and recovery, Journal of Services Marketing, 27(3), 223-233.

Collie, T A., Baverley, S. and Graham, B. (2000). Investing in interactional justice: a study of the fair process effects within a hospitality failure context, journal of hospitality @ amp;Tourism Research, 24, 448-472.

Conlon, D., and Murray, N. (1996). Customer perceptions of corporate responses to product complaints: the role of explanations, The Academy of Management Journal, 39 (4), 1040-1046.

Elliwati J., Purwanto, B.M., and Dhammesta, B.S. (2012). The effect of perceived justice on customer satisfaction in the service recovery context: testing mediating variables, Journal of Service Science, 5(2), 1-14.

Ennew, C., and Schoefer, K. (2003). Service failure and service recovery in tourism: a review of christel dehaan tourism and travel research institute, nottingham university Business School.

Gronroos, C. (1988). Service quality: the six criteria of good perceived service quality, Review of Business, 9 (Winter), 10-13.

Hart, C., Heskett, J., and Sesser, W. J. (1990). The profitable art of service recovery. Harvard Business Reviews , 68 (4), 148-156.

Holbrook Jr, R. L. and Carol, T. K. (2001). Consumer perceptions of justice in service transactions: the effects of strong and weak ties, Journal of Organizational Behavior, 22, 743-757.

Johnston, R., and Michel, S. (2008). Three outcomes of service recovery customer recovery, process recovery and employee recovery, International Journal of Operations and Production Management, 28(1), 79-99.

Kim, T, Kim, W. G., and Kim, H. (2009). The effects of perceived justice on recovery satisfaction, trust, word-of-mouth and revisit intention in upscale hotels, Tourism Management, 30, 51-62.

McCollough, M A.; Berry, LL and Manjit, S. Y. (2000). An empirical investigation of customer satisfaction after service failure and recovery, Journal of Service Research, 3(2), November, 121-137.

Miche,1 S., and Meuter ,M.. L .(2008). The service recovery paradox: True but overrated? International Journal of Service Industry Management, 2(2), 30-33 
Namkung, Y., and Jang, S. (2010a). Service failures in restaurants: which stage of service failure is the most critical, Cornell Hospitality Quarterly, 51(3), 323-343.

Namkung, Y., and Jang, S. (2010b). Effects of perceived service fairness on emotions, and behavioural intentions in restaurants, European journal of marketing, 44(9), $1233-1259$.

Nikbin, D., Ismail, I., Marimuthu, M., and Jalalkamali, M. (2010). Perceived justice in service recovery and recovery satisfaction: the moderating role of corporate image, International Journal of Marketing Studies 2(2)

Okeke, T. C; Olise, M.C. and Eze, G.A (2012). Research methods in business and management science, ( ${ }^{\text {nd }}$ Edition), Enugu, Iyke Venture Publications.

Rio-Lanza, A. B.; Vazquez-Casielles and Ana, M. D (2008). Satisfaction with service recovery: perceived justice and emotional responses, Journal of Business Research: 1-7

Schiffman, L .G., and Leslie, L. K. (2007). Consumer behavior, 9th edition, New Jersey: Pearson Education, Inc.

Smith, A., Bolton, R., and Wagner, J. (1999). A model of customer satisfaction with service encounters involving failure and recovery, Journal of Marketing Research, 36(3), 356-72.

Solomon, M. R. (2004). Consumer behavior: buying, Having and Being, 6th edition, New Jersey: Pearson Education, Inc.

Tabassum, A. and Rahman, T. (2012). Differences in consumer attitude towards selective fast food restaurants in Bangladesh: an implication of multi attribute attitude model: World Review of Business Research, 2(3), 12-27.

Tax, S., Brown, S., and Chandrashekaran, M. (1998). Customer evaluations of service complaint experience: implications for relationship marketing, Journal of Marketing, 62(2), 60-76.

Zeithaml, V.A., Bitner, M. J. and Gremler, D.D. (2009). Services Marketing 5th Edition, McGraw-Hill.

Zeithaml, V.A., Bitner, M. J. and Gremler, D.D. (2009). Services Marketing 5th Edition, McGraw-Hill.

Zemke, R., and Bell, C. (1990). Service recovery: doing it right the second time, training, Journal of Quality Management, 27(6), 42-48 